$$
\begin{aligned}
& {[11.8 \div \div 3} \\
& 650250 \\
& 13040 \therefore .
\end{aligned}
$$

PRELTIMARY REPORT OF CASCADE PROSPICT, KX119.30 PRINCE OF WALES ISLAND, KETCHIKAN DISTRICT, NIASKA May 15, 3.939

\title{
Location and Acoessibility:
}

The Cascade prospect is located four miles wost of Hollis, via tra1l, and two miles southwest of the Hope mine on Prince of Weleg Island. The trall to the property starts at Hollis, continues along the old horse tramway to the Hopa mine, and thence continues up the mountain to the old workings situated between elevations of 1300 and 1500 feet. Thase elevations represent timber line in this locality.

Ro111s, Alaska.

The owner and operator of th1s one clatm is J. J. Matuska of

\section{E1story:}

The alsoovery of gold on this clatm was made by R. Kruckolis of Xetch1kan, Alaska in the year 1900. The following year the property was optioned to a company which orove the present tunnels. During the development a large quartz boulder, welghing two and one-fourth tons, wag found on the surface above the upper tunnel. Thls boulder contained considereble freo gold and it was broken up and shlpped. The company operated two seasons and dropped the opt1on.

In $1914 \mathrm{~J}$. IeBrandt and Charles Redienloo built en arragtre and operated during the season with a production of 30 ounces of gold. The following year they installed a three-ton stamp mill and operated that seagon with a small unguccessiul production.

The property remained 1ale until the year 1932, et which time 1t was staked by Tom Stevens. Ifttlo or no work, other then a littlo prospecting, wes done by Stevens. The property was aold for \$50 to John Bulfers who tried to sell, but dropped bls title the followlng year. The present owner, J. J. Mutuaka, restaked the property in September, 1938.

Goology and Development:

A short description of the property is given in U. S. G. S. bulletin 34?, "Ketchikan and Frangell Minlng Distrlcta, Alaska" by F. E. \& C. W. Wight, pp. 161-162, es follows: 
"The developments consist chleflg of two drift tunnels, and in the upper one a quartz vein is well exposed. The vein averages 2 feet in width and fills an old eracture crack in an eltered basio intrusive. The lower tunnel, wilch was driven to under cut the veln, is 300 feet in length and crosscuts intrusive rocks and dikes of several different types, but does not expose the vein. The originel sedimentary rocks in this area have been profoundly altered by the intrualves, and epidotization is widespread. The vein strikes N. 530 N., dips 700 SW., and hes been follorred for about 175 feet in the upper tunnel. ******

On the date of visit the surpace was oovered with heavy snow and surface outcroppings were not observed. The lover tunnel, elevetion 1300 feet, was caved a few feet in from the portal. Turther development in the upper tunnel, since the above report, consists of a crosgcut into the footwall 22 feet in length at a point 21 peet back from the face. This tunnel was driven on the vein over 1ts entire length of 175 feet. The orosscut showg only bard elagtic greengtone. At a point 4 leat back from the face a small quartz lense is exposed for a distance of 36 feot. It hes a width of two feet, has a bended character, and lies on the footwall side of the veln, the letter oonsisting of a parallel mineralized shear in the the remainder of the vein consists meinly of these shears, some of which are fllled with quartz, verying up to a fow inches in width. Small lenses of quartz ocour along the stringers. The ore that was milled wes reported to have been taken from surface cuts and a small lense of heary sulphicle ore located in the oreek bed 30 leet west of the upper tunnel portel. This lense was covered with deep snow, but was reported to be I5 feet in leggth, everages 8 to 10 inches in wldth, and oontaing gold and silver values averaging \$100 per ton.

Both post and pre-veln movement shows in the vein mainly of horizontal direotion. The walls are slightly fractured, the vein banded, and the quartz is frozen in spots.

Mineralization:

The metallic minerals noted in the ore were unevenly distributed from nearly massive in spots to very lean in otherg. They conslated of froe gold, s13rer, pyrite, sphelerite, chalcopyrite and gelena. The gold and silver values were reported as blehest in the areas of greatest concentration of the sulphides. The gangue minerals consisted of wite to gray quartz, calcite and pleces of altered vral rook. Pyrite minerallzation is evident along and penetreting the walls of the voin, but is mostly confined to the walls of the shears. 


\section{Sampiling and Assays:}

A total of four channel samples were taken in the upper tunnel, elevation 1400 foet. Show prevented sampling the sulphide lenge crossing the creek bed, whioh was reported averaging nearly $\$ 100$ per ton in gold and silver.

Sample No, 607 was taken in the upper tunnel at a point in the roof 10 feet back from the face across 27 inches of quartz. This gave returns of 0.24 oz. gold and $0.40 \mathrm{oz}$. silver per ton.

Samplo No. 608 was taken 18 feet back from the face across 13 inches of quartz. This gave returns of $0.14 \mathrm{oz}$. gold and $0.40 \mathrm{oz}$. silver per ton.

Sample No. 609 was cut from the roor 23 reet back from the face across 12 inches of quartz and mineralized wall rook. This gave returns of $0.50 \mathrm{oz}$. of gold and $0.70 \mathrm{oz}$. of silver per ton.

Sample No. 610 was taken 30 feet in from the portal across 4 inches of quartz. Th19 gave returms of $0.12 \mathrm{oz}$. gold and 1.60 oz. silver per ton.

gurfeog.

Higher values were reported by Matuske from the opencuts on the

Machinery:

The old mill bulldings and machinery are obsolete, but Matugke has installed a small rooker type mill of a fow hundred pounds dally capacity. In addition he hes a $4 \times 6^{\prime \prime}$ Mine, Mill sc Smelter Compeny faw orusbor and $83 \frac{1}{2} x$ ? Wilfley table. For power, be is lastalling on 18-inch Pelton wheol using the water from the small creek alongside the tunnel. This is a pexy small creek whlch hes it sourco mainly from melting snow. There $1 \mathrm{~s}$ considerable timber in the valley below the turnels. Large water power development is lacking. 